\title{
Cultivars and sequential harvesting influence physiological and functional quality of strawberry fruits
}

Pankaj Kumar KanNaUJIA, Ram ASREY*, Kavita BhAtiA, Sunil Kumar JHA

Division of Post Harvest Technology, Indian Agricultural Research Institute, New Delhi, India,ramu_211@yahoo.com
${ }^{*}$ Correspondence and reprints

Received 5 June 2013 Accepted 19 September 2013

Fruits, 2014, vol. 69, p. 239-246 (C) 2014 Cirad/EDP Sciences All rights reserved DOI: $10.1051 /$ fruits/2014013 www.fruits-journal.org

RESUMEN ESPAÑOL, p. 246
Cultivars and sequential harvesting influence physiological and functional quality of strawberry fruits.

Abstract - Introduction. Strawberry is basically a temperate fruit, but, due to its short production cycle (100-120 days), it has now become the fastest growing crop in the tropical and sub-tropical regions of the Asian nations. In India, farmers of northern plain regions transplant the strawberries before the onset of the winter and keep on harvesting until early summer. Not much is known about the impact of the harvesting season (winter and summer) on the accumulation of health-promoting substances or on quality traits. Considering the existing research gaps and practical utility, the present study was undertaken. Materials and methods. Four varieties were grown on raised beds with black polythene mulch, and a drip and fertigation system. Fruits were harvested at the $3 / 4$ colour (scarlet) development stage and observations were recorded on different physiological and functional attributes consecutively during three harvesting months. Results and discussion. Our results indicated that both cultivars and harvesting months affected the physiology and functional quality of strawberry fruit. Anthocyanin, ascorbic acid and total antioxidants were found to be higher during March. Ascorbic acid content registered $\approx 50 \%$ reduction during advance summer harvesting (April). Among the tested varieties, Camarosa gave better results during all three harvesting months in terms of desirable quality traits. Conclusion. Our findings show that there are some varieties such as Camarosa which have the potential to produce functionally superior fruits over other cultivars even during early summer. The information presented may be helpful in selection of suitable cultivars, and postharvest handling and processing measures for strawberry fruits harvested during different months.

India / Fragaria ananassa / fruits / quality / harvesting date / respiration / health foods

\section{Le cultivar et la date de récolte influencent la qualité physiologique et fonctionnelle de la fraise.}

Résumé - Introduction. La fraise est fondamentalement un fruit tempéré, mais, du fait de son court cycle de production (100 à 120 jours), elle est maintenant devenue la production à croissance la plus rapide dans les régions tropicales et subtropicales des pays asiatiques. En Inde, les agriculteurs de la région des plaines du nord transplantent les fraisiers avant le début de l'hiver et continuent à récolter jusqu'au début de l'été. L'incidence de la saison de récolte (hiver ou été) sur l'accumulation de substances favorables à la santé ou sur certains critères de qualité est peu connue. Notre étude a été entreprise du fait des lacunes existantes de la recherche dans ce domaine et de l'utilité pratique de ce paramètre. Matériel et méthodes. Quatre variétés ont été cultivées sur les rangs couverts d'un paillis de polythène noir et munis d'un système de goutte-à-goutte avec fertigation. Les fruits ont été récoltés au stade de $3 / 4$ mûr (écarlate) et des observations ont été effectuées sur différents caractéristiques physiologiques et fonctionnelles pendant trois mois de récolte successifs. Résultats et discussion. Nos résultats ont indiqué qu'à la fois le cultivar et le mois de récolte ont affecté la physiologie et la qualité fonctionnelle de fraise. Les taux d'anthocyanine, d'acide ascorbique et les antioxydants totaux se sont révélés supérieurs lors des récoltes de mars. La teneur en acide ascorbique a été réduite d'environ $50 \%$ pendant la récolte de début d'été (avril). Parmi les variétés testées, Camarosa a donné de meilleurs résultats au cours des trois mois de récolte pour les caractéristiques désirables de qualité. Conclusion. Nos résultats ont prouvé qu'il y a certaines variétés comme Camarosa qui ont le potentiel de produire des fruits fonctionnellement supérieurs à d'autres cultivars même en début d'été. L'information obtenue pourrait être utile pour la sélection d'un cultivar approprié et la mise au point de mesures de manutentions et de traitements après-récolte pour des fraises récoltées à différents mois.

Inde / Fragaria ananassa / fruits / qualité / date de récolte / respiration / aliment santé pour homme 


\section{Introduction}

Strawberry (Fragaria $\times$ ananassa Duch.) is one of the most delicious and refreshing fruits in the world. Being a rich source of vitamins and minerals coupled with a delicate flavour, strawberry has now become an important table fruit of millions of people around the globe. Strawberries are good sources of natural antioxidants [1-3]. In addition to the usual nutrients such as vitamins and minerals, strawberries are also rich in anthocyanins, flavonoids and phenolics [4]. In India, strawberry was introduced during the early sixties but could not be popularised for several reasons [5]. However, in the past decade and a half, it has become a favourite fruit among growers because of its remunerative prices and higher profitability [6]. Furthermore, availability of day-neutral and high-yielding varieties and standardisation of agro-techniques have resulted in a phenomenal increase in its area of production, particularly near towns and big cities.

Strawberry is the only fruit which starts providing earnings to the farmers within the first 100 days after its planting. In the light of the documented facts, it is confirmed that the season and cultivar affect the nutrient accumulation in fruits [7-9]. It is hypothesised that the harvesting season will also influence the physiological and functional qualities of strawberry fruits.

Chandler and Sweet Charlie had been the ruling varieties of northern India. In recent years, several new introductions have been added to the varietal wealth of the strawberry. Among the introduced strawberry varieties, Winter Dawn and Camarosa have had wider adoption in production catchment areas. For effective postharvest handling and processing of any fruit, the basic information on its varietal response to sequential harvesting is of absolute importance. Not much is known about the impact of the harvesting season on accumulation of health-promoting substances or on quality traits. Furthermore, the effect of delayed harvesting on physical and physiological traits of commercially grown strawberries is little studied. Considering the existing research gaps and practical utility of region-specific work, systematic studies were conducted on the "Physico-chemical and functional properties of strawberry fruit in relation to cultivar and sequential harvesting".

\section{Materials and methods}

\subsection{Experimental site and fruit material}

Strawberry fruits of the Camarosa, Chandler, Sweet Charlie and Winter Dawn cultivars were sourced from Beniwal Strawberry Farm, in the NCR region near Delhi [lat. $28.08^{\circ} \mathrm{N}$, long. $77.12^{\circ} \mathrm{E}$ and 750 feet (228.6 $\mathrm{m}$ ) above mean sea level]. The four varieties were grown on raised beds with black polythene mulch, and a drip and fertigation system. Fruits were harvested at the $3 / 4$ colour development stage, during February (winter), March (spring) and April (summer). Freshly harvested fruits were brought to the laboratory for physico-chemical analysis work in the Postharvest Technology Division at the Indian Agricultural Research Institute, New Delhi, India. Analysis was performed during February, March and April for given parameters.

\subsection{Physical parameters}

Weight was taken for 15 fruits and expressed as average fruit weight. Fruit firmness was determined by using a texture analyser (model TA+Di, Stable Micro Systems, UK) using a compression test. The sample fruits were compressed using a cylindrical probe ( $2 \mathrm{~mm}$ diameter) with preand post-test speeds of $2 \mathrm{~mm} \cdot \mathrm{s}^{-1}$ and $0.5 \mathrm{~mm} \cdot \mathrm{s}^{-1}$, respectively. The first peak force $(\mathrm{N})$ in the force deformation curve was taken as the firmness of the sample.

\subsection{Respiration rate}

The respiration rate was measured by placing 10 fruits in a 1-L-capacity container hermetically sealed with a silicone rubber septum for $4 \mathrm{~h}$. After the specified time the headspace gas was sucked through a hypodermic hollow needle and placed in an 
auto gas analyser (Model: Checkmate $9900 \mathrm{O}_{2} / \mathrm{CO}_{2}$, PBI Dansensor, Denmark) and the resultant values were expressed as $\mathrm{mL} \mathrm{CO} 2 \cdot \mathrm{kg}^{-1} \cdot \mathrm{h}^{-1}$.

\subsection{Biochemical and functional parameters}

The total soluble solids of samples were estimated using a Fisher Scientific hand refractometer with a score of $0-50{ }^{\circ}$ Brix. The results were expressed in $\%$ at $20^{\circ} \mathrm{C}$ Titratable acidity was estimated by the titration method [10]. The aliquot of the sample prepared was titrated with $0.1 \mathrm{~N} \mathrm{NaOH}$ using a few drops of $1 \%$ phenolphthalein solution as an indicator. The titre value was calculated for calculating the values as per cent anhydrous citric acid. Total sugars were estimated [10] taking $10 \mathrm{~g}$ of strawberry fruit juice and using lead acetate to remove the excess of lead. Lead free aliquots were examined by titrating against boiling Fehling's solution, which had previously been standardised using methylene blue indicator. The data were expressed in \%. For ascorbic acid estimation, ten $\mathrm{mL}$ of strawberry fruit juice sample were taken, the volume of which was made up to $100 \mathrm{~mL}$ with $3 \% \mathrm{HPO}_{3}$; it was then filtered and centrifuged [10]. The prepared fruit sample was taken into a conical flask and titrated against standardised dye. The titre value was noted; it was used for calculation of ascorbic acid content in the sample.

Total anthocyanins in strawberry were estimated [10]. Juice extracts were centrifuged at $10,000 \mathrm{rpm}$ for $20 \mathrm{~min}$ at $4{ }^{\circ} \mathrm{C}$ and absorbance measurements were made at $435 \mathrm{~nm}$ using a $1.0-\mathrm{cm}$ path length cuvette. Total anthocyanins were measured in $\mathrm{mg} \cdot 100 \mathrm{~g}^{-1}$ of strawberry sample. Antioxidant activity was measured by the cupric reducing antioxidant capacity (CUPRAC) method and results were expressed as $\mu$ mol Trolox Eq.g ${ }^{-1}[7]$.

\subsection{Statistical analysis}

Our experiment was laid out in a factorial randomized block design (RBD). Two years' data obtained from three replicates and each treatment consisting of 45 fruits in respect to the various parameters were subjected to analysis of variance (ANOVA). Sources of variation were harvesting months and cultivars. Differences were considered to be significant at $P \leq 0.05$ (95\% confidence level). All analyses were performed with the SPSS software package.

\section{Results and discussion}

\subsection{Fruit weight}

Individual fruits of strawberry with a weight of $10 \mathrm{~g}$ are considered as "A" grade. Irrespective of the variety, March harvesting gave the highest average fruit weight (figure 1). Irrespective of the variety, the lowest average weight was found in early and late harvesting. On a weight basis, the cultivar Camarosa produced comparatively bigger fruits than the other cultivars. The reason behind the comparatively bigger fruits in March harvesting could be linked to efficient absorption of plant nutrients by the roots, and faster cell division and elongation due to favourable temperature [11].

\subsection{Fruit firmness}

Fruit firmness was significantly affected by the harvesting months and tested varieties, and the interaction of these two factors was found to be significant (figure 1). The firmness was highest in the month of February followed by March and April. Among the varieties, Camarosa consistently produced firmer fruits throughout the harvesting span cutting across winter and summer months (except April). Fruit firmness is governed by several factors, of which fruit pectin content, dry matter and stage of harvesting are considered the major ones. The increased firmness in winter harvest might be due to pectin synthesis and jellying behaviour [12]. The other possibility of higher firmness in winter harvest could be linked with fruit dry matter, because the cell turgor can affect the mechanical resistance of the fruit tissues [11]. 
P.K. Kannaujia et al.

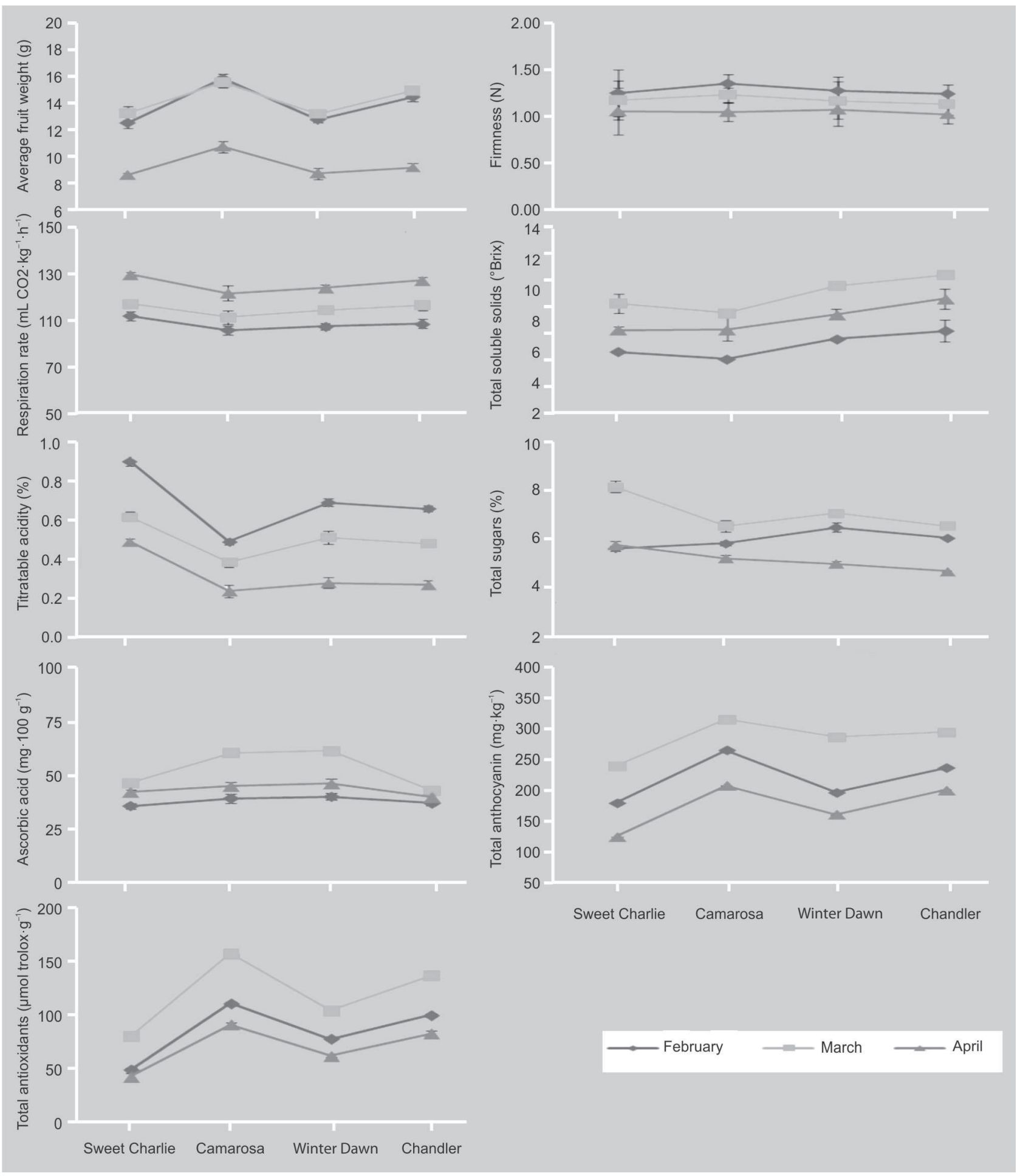

Figure 1.

Effect of cultivars and sequential harvesting on the fruit weight, firmness, respiration rate, total soluble solids, titratable acidity, total sugars, ascorbic acid, total anthocyanins and total antioxidants of freshly harvested strawberry fruit. Data are the means of 45 fruit analyses across three replications. Standard deviation is represented by vertical bars (Delhi region, India). 


\subsection{Respiration rate}

Harvesting months and varieties significantly influenced the respiration rate of the freshly harvested fruits during the entire harvesting period. Irrespective of the cultivar, April-harvested fruits recorded the highest respiration rate followed by March and February. Winter Dawn recorded the lowest respiratory rate over the other varieties ( $f i g$ ure 1). In general, these findings indicated that the fruit respiration rate is influenced by the growing environment and genotype. The respiratory physiology of both climacteric and non-climacteric fruits is linearly influenced by pulp composition (carbohydrates, pectin, protein and antioxidants) and storage environments - ambient, [controlled atmosphere/modified atmosphere] ratio and cold storage [13].

\subsection{Total soluble solids}

Harvesting months and cultivars both significantly affected total soluble solids (TSS) content in the fruits. Irrespective of the variety, March-harvested fruits recorded the highest TSS, ranging from $9.8^{\circ} \mathrm{Brix}$ to $11.54^{\circ}$ Brix, followed by April and February. The cultivar Chandler produced higher TSS value fruits than the other varieties throughout the three months (figure 1). Previous researchers reported that TSS are more dependent on environmental conditions than genetic inheritance [14], while Kader found that fruits from summer-harvested strawberries were higher in TSS than those of winter-harvested fruits [15]. In the case of our findings, where the highest TSS were obtained in March-harvested fruits, the above established finding was further confirmed. Wang and Camp also reported that strawberry exposed to high temperatures (22$30{ }^{\circ} \mathrm{C}$ ) was positively affected in respect to soluble solids upto a certain extent [16].

\subsection{Titratable acidity}

The fruit acidity range was found to vary between $0.3 \%$ and $0.93 \%$ during the different months among the tested varieties. The highest acidity was recorded in Februaryharvested strawberry fruits followed by March and April (figure 1). Among the varieties, Camarosa registered the lowest level of titratable acidity (TA) during the three consecutive months, i.e., February, March and April. Citric acid is the primary titratable acidity contributing organic acid found in the strawberry fruits; as the day/night temperature increased, organic acid content decreased [16]. The higher level of acidity in February-harvested fruits may result from decreased respiration and thereupon higher accumulation of organic acids during summer. It is further iterated that TA content in the fruit tissues is also influenced by the species, cultivar and even by the disease incidence [17].

\subsection{Total sugars}

Total sugar was recorded as highest (8.54\%) during March in the Sweet Charlie cultivar (figure 1). The cultivar Camarosa showed less fluctuation in total fruit sugar content during winter and summer months. Preharvest factors such as average temperature and relative humidity, along with available heat and light intensity, are also important factors in determining the sugar level and its composition in developing fruits [13, 18].

\subsection{Ascorbic acid}

It is generally known that fruits produced during chilly winter are rich in phytonutrients and secondary metabolites including ascorbic acid (AA). Contrary to this notion, fruits harvested during March recorded about double ascorbic acid recovery compared with February harvesting. Similar to harvesting months, cultivars also exhibited significant differences in respect to their ascorbic acid recovery during different harvesting months (figure 1). The greater difference in AA recovery during the early summer (March) fruiting may be due to the cultivar and higher anabolism and catabolism ratio favoured by the temperature, inducing ascorbic acid biosynthesis [8, 19]. Hansen and Waldo reported that strawberries grown under shade have significantly less AA than those exposed to normal sunlight [20]. Higher irradiative conditions favour high AA content, while wet, cloudy weather results in low values. In Delhi conditions (the experimental site), February generally remains full of smog and fog, 
which contribute to low solarisation (table I).

\subsection{Total anthocyanins}

Significant differences were found in the anthocyanin content of fruits harvested during February, March and April, whatever the four varieties studied. Strawberry fruit harvested during March exhibited the maximum anthocyanin content, ranging from (256.34 to 328.22$) \mathrm{mg} \cdot \mathrm{kg}^{-1}$ (figure 1) Camarosa was found to be superior to the other varieties with respect to anthocyanin content. A linear increase in the total anthocyanin recovery was recorded during favourable day and night temperatures, i.e. March. This might have happened due to higher biosynthesis of anthocyanins during March, which was found to be significantly lower during February and April. Lower recovery of anthocyanins during February and April might be attributed to metabolite inter-conversion with carbohydrate [21]. Maro et al. also reported increased pigment biosynthesis in raspberries grown under a subtropical region (congenial climatic conditions) of Brazil [8]

\subsection{Antioxidant activity}

Total antioxidant contents were found to be significantly different in strawberry fruits harvested during the three months considered (figure 1). Irrespective of the variety, it was found to be highest in March $\left(166.72 \mu \mathrm{mol}\right.$ Trolox $\left.\cdot \mathrm{g}^{-1}\right)$ and lowest in fruits harvested in April $(57.91 \mu \mathrm{mol}$ Trolox $\left.\cdot \mathrm{g}^{-1}\right)$. Irrespective of the harvesting month, Camarosa exhibited the maximum antioxidant content followed by Chandler, Winter Dawn and Sweet Charlie. Total antioxidants are mainly contributed by phenolics, ascorbic acid and anthocyanins. The synthesis of the metabolites has been reported to be optimum in fruits developed under favourable growing conditions [22]. In our results, the total antioxidant activity was found to be the highest in the Marchharvested fruits and the total antioxidant value was drastically reduced under stress conditions (February and April). This may be attributed to the high antioxidant contributing capacity of the anthocyanins and ascorbic acid, whose concentrations were found to be increased during March in our earlier findings.

Table I.

Average monthly temperature, relative humidity, rainfall and cloud cover during strawberry growing and harvesting period (Delhi region, India).

\begin{tabular}{|c|c|c|c|c|c|c|c|}
\hline & \multirow[t]{2}{*}{ Date } & \multicolumn{3}{|c|}{ Temperature $\left({ }^{\circ} \mathrm{C}\right)$} & \multirow{2}{*}{$\begin{array}{l}\text { Relative humidity } \\
\text { (\%) }\end{array}$} & \multirow{2}{*}{$\begin{array}{l}\text { Rainfall } \\
\text { (mm) }\end{array}$} & \multirow{2}{*}{$\begin{array}{c}\text { Cloud cover } \\
\text { (Okta) }\end{array}$} \\
\hline & & Maximum & Minimum & Average & & & \\
\hline \multirow[t]{2}{*}{2010} & November & 28.56 & 12.42 & 19.83 & 60.59 & 0.00 & 2.29 \\
\hline & December & 22.47 & 5.54 & 13.95 & 67.27 & 0.00 & 2.36 \\
\hline \multirow[t]{6}{*}{2011} & January & 18.07 & 5.37 & 11.72 & 67.03 & 0.00 & 2.54 \\
\hline & February & 23.06 & 9.52 & 16.29 & 70.39 & 1.81 & 2.28 \\
\hline & March & 29.17 & 13.5 & 21.33 & 62.09 & 0.11 & 1.31 \\
\hline & April & 35.04 & 17.81 & 26.42 & 44.75 & 0.12 & 0.72 \\
\hline & November & 28.79 & 12.61 & 20.70 & 60.83 & 0.00 & 2.31 \\
\hline & December & 22.62 & 5.67 & 14.15 & 67.19 & 0.00 & 2.38 \\
\hline \multirow[t]{4}{*}{2012} & January & 18.70 & 5.45 & 12.11 & 72.59 & 0.47 & 2.74 \\
\hline & February & 22.62 & 7.94 & 15.28 & 54.39 & 0.00 & 1.46 \\
\hline & March & 29.92 & 12.70 & 21.31 & 50.88 & 0.62 & 1.09 \\
\hline & April & 35.40 & 19.30 & 27.35 & 53.76 & 0.35 & 0.81 \\
\hline
\end{tabular}




\subsection{Effect of cloud cover on antioxidant content of strawberry fruits}

To establish the relationship between cloud cover and the antioxidant content of strawberry fruits, plots were drawn (figure 2). The linear relationship was first tested but yielded very poor fit. Hence, a second-order equation was tested:

(1): $y_{\text {Camarosa }}=-53.39 x^{2}+204.2 x-28.13$; $R^{2}=1$

(2): $y_{\text {Chandler }}=-42.73 x^{2}+162.7 x-7.75$; $R^{2}=1$

(3): $y_{\text {Winter Dawn }}=-32.65 x^{2}+123.3 x+0.25$; $R^{2}=1$

(4): $y_{\text {Sweet Charlie }}=-32.56 x^{2}+127.3 x-31.04$; $R^{2}=1$

The developed empirical relationships presented in equations (1), (2), (3) and (4) showed a quadratic response for antioxidant content to cloud cover for all four varieties. This might be due to poor photosynthetic activities and source-sink relationships [23]. The coefficient of determination $R^{2}$ was recorded to be 1 for all four varieties, indicating a complete fit. It can be concluded that across the range of cloud cover, the antioxidant content showed an increase up to 1.2 cloud cover corresponding to the month of March and thereafter tended to decline. Where foggy weather is the common phenomenon, it is advisable to schedule the strawberry planting in such a way that the bulk of the picking may be done during March in order to have antioxidant-rich fruits.

\section{Conclusion}

Congenial climatic conditions (neither too cool nor too hot) produced nutritionally rich strawberry fruits harvested during March. Besides the picking month, varietal difference was also found to be linked with fruit quality. In addition, the information presented may be helpful in adopting suitable postharvest handling measures for strawberry fruits harvested during different months. Further research is required to

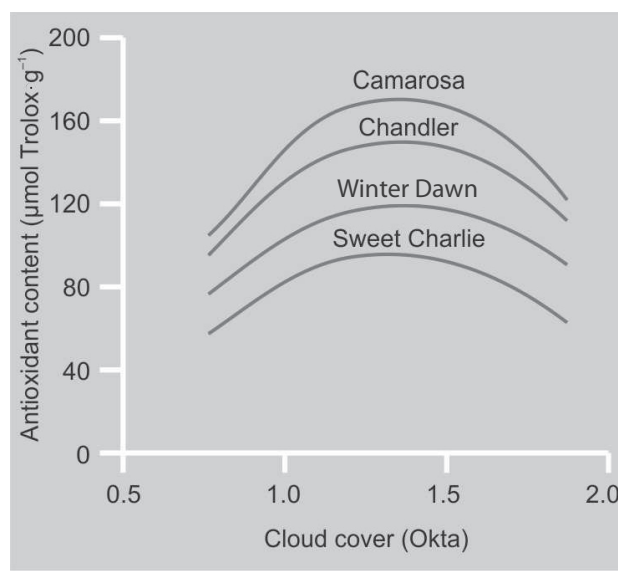

Figure 2.

Effect of cloud cover on antioxidant content of four cultivars of strawberry fruits (Delhi region, India).

work out the relationships among the harvesting season, cultivar and quality of the processed strawberry products.

\section{References}

[1] Wang H., Cao G., Prior R.L., Total antioxidant capacity of fruits, J. Agric. Food Chem. 44 (1996) 701-705.

[2] Heinonen I.M., Meyer A.S., Frankel E.N., Antioxidant activity of berry phenolics on human low-density lipoprotein and liposome oxidation, J. Agric. Food Chem. 46 (1998) 4107-4112.

[3] Wang S.Y., Lin H.S., Antioxidant activity in fruit and leaves of blackberry, raspberry, and strawberry varies with cultivar and developmental stage, J. Agric. Food Chem. 48 (2000) 140-146.

[4] Voca S., Duralija B., Druzic J., Babojelic M.S., Dobricevic N., Cmelik Z., Influence of cultivation systems on physical and chemical composition of strawberry fruits cv. Elsanta, Agric. Conspec. Sci. 71 (2006) 71-74.

[5] Singh R., Asrey R., Growth, earliness and fruit yield of micro-irrigated strawberry as affected by planting time and mulching in semi-arid regions, Indian J. Hortic. 62 (2005) 148-151.

[6] Asrey R., Singh R., Kumar A., Maturity, transportation and storage studies in strawberry fruits, J. Food Sci. Technol. 45 (2008) 145-147.

[7] Apak R., Guclu K., Ozyurek M., Karademir S.E., Novel total antioxidant capacity index for dietary polyphenol and vitamins $\mathrm{C}$ and $\mathrm{E}$, using their cupric ion reducing capability in the presence of neocuproine, CUPRAC method, J. Agric. Food Chem. 52 (2004) 7970-7981. 
[8] Maro L.A.C., Pio R., Guedes M.N.S., Abreu M.P., Curi P.N., Bioactive compounds, antioxidant activity and mineral composition of fruits of raspberry cultivars grown in subtropical areas in Brazil, Fruits 68 (2013) 209-217.

[9] Pincemail J., Kevers C., Tabart J., Dommes J., Cultivar, culture, conditions and harvest time influence phenolics and ascorbic acid contents and antioxidant capacity of strawberry, J. Food Sci. 77 (2012) 205-210.

[10] Anon., Official methods of analysis of AOAC International, 17th ed., Assoc. Off. Anal. Chem., Gaithersburg, U.S.A., 2000.

[11] Cordenunsi B.R., Nascimento J.R.O., Genovese M.I., Lajolo F.M., Influence of cultivar on quality parameters and chemical composition of strawberry fruits grown in Brazil, J. Agric. Food Chem. 50 (2002) 2581-2586.

[12] Werner R.A., Frenkel C., Rapid changes in the firmness of peaches as influenced by temperature, HortScience 13 (1978) 470-471.

[13] Lee S.K., Kader A.A., Preharvest and postharvet factors influencing vitamin $C$ content of horticultural crops, Postharvest Biol. Technol. 20 (2000) 207-220.

[14] Shaw D., Response to selection and associated changes in genetic variance for soluble solids and titratable acids content in strawberries, J. Am. Soc. Hortic. Sci. 115 (1990) 839-843.

[15] Kader A.A., Quality and its maintenance in relation to the postharvest physiology of strawberry, in: Dale A., Luby J.J. (Eds.), The strawberry into the 21st century, Timber Press, Portland, OR, U.S.A., 1991.
[16] Wang S.Y., Camp M.J., Temperatures after bloom affect plant growth and fruit quality of strawberry, Sci. Hortic. 85 (2000) 183-199.

[17] Wang S.Y., Maas J.L., Payne J.A., Galletta G.J., Ellagic acid content in small fruits, mayhaws and other plants, J. Small Fruit Vitic. 2 (1994) 39-49.

[18] Watson R., Wright C.J., McBurney T., Taylor A.J., Linforth R.S.T., Influence of harvest date and light integral on the development of strawberry flavour compounds, J. Exp. Bot. 53 (2002) 2121-2129.

[19] Nour V., Trandafir I., Ionica M.E., Ascorbic acid, anthocyanins, organic acids and mineral content of some black and red currant cultivars, Fruits 66 (2011) 353-362.

[20] Hansen E., Waldo G.F., Ascorbic acid content of small fruits in relation to genetic and environmental factors, Food Res. 9 (1944) 453-461.

[21] Kalt W., Forney C.F., Martin A., Prior R.L., Antioxidant capacity, vitamin C, phenolics and anthocyanins after fresh storage of small fruits, J. Agric. Food Chem. 47 (1999) 4638-4644.

[22] Jin P., Wang S.Y., Wang C.Y., Zheng Y., Effect of cultural system and storage temperature on antioxidant capacity and phenolic compounds in strawberries, Food Chem. 124 (2011) 262-270.

[23] Bunce J.A., Sicher R.C., Daily irradiance and feedback inhibition of photosynthesis at elevated carbon dioxide concentration in Brassica oleracea, Phytosynthetica 41 (2003) 481-488.

\section{El cultivar y la fecha de cosecha influencian la calidad fisiológica y funcional de la fresa.}

Resumen - Introducción. La fresa es fundamentalmente un fruto de clima templado, pero, dado su corto ciclo de producción (de 100 a 120 días), actualmente se ha convertido en la producción de crecimiento más rápido en las regiones tropicales y subtropicales de los países asiáticos. En la India, los agricultores de la región de las llanuras del norte trasplantan las fresas antes del comienzo del invierno y siguen cosechando hasta el comienzo del verano. Se conoce poco la incidencia de la estación de cosecha (invierno o verano) en la acumulación de sustancias favorables para la salud o en ciertos criterios de calidad. Nuestro estudio se llevó a cabo dadas las lagunas existentes de investigación en este campo y la utilidad práctica de este parámetro. Material y métodos. Se cosecharon cuatro variedades en las filas cubiertas de un mantillo de polietileno negro y provisto de un sistema de goteo con riego fertilizante. Se cosecharon los frutos en el estado de $3 / 4$ de madurez (escarlata) y se efectuaron observaciones en diferentes características fisiológicas y funcionales durante tres meses sucesivos de cosecha. Resultados y discusión. Nuestros resultados indicaron que a la vez el cultivar y el mes de cosecha afectaron la fisiología y la calidad funcional de la fresa. Los índices de antocianinas, de ácido ascórbico y los antioxidantes totales resultaron ser superiores durante las cosechas de marzo. El contenido de ácido ascórbico se redujo de cerca de un 50\% durante la cosecha de comienzos de verano (abril). Entre las variedades testeadas, Camarosa dio los mejores resultados a lo largo de tres meses de cosecha para las características de calidad deseadas. Conclusión. Nuestros resultados probaron que existen ciertas variedades como Camarosa que tienen un potencial para producir frutos funcionalmente superiores a otros cultivares, incluso a comienzos de verano. La información obtenida podría ser útil para seleccionar un cultivar apropiado y establecer medidas de manutenciones y de tratamientos poscosecha para las fresas cosechadas en meses diferentes.

India / Fragaria ananassa / frutas / calidad / fecha de recolección / respiración / alimentos sanos 